\title{
Enhancement of Operating Efficiency Of The Central Coal-Preparation Plant of "MMK - UGOL" Ltd. Under Current Conditions
}

\author{
Maksim Basarygin ${ }^{1 *}$ \\ ${ }^{1}$ Central coal-preparation plant of JSC «MMK - UGOL», 652607, 27/1 Teleut st, Belovo, Russia
}

\begin{abstract}
In this article the subject of enhancement of operating efficiency of the central coal-preparation plant of OOO «MMK-UGOL» is encompassed. Modern trends in the development of technologies and equipment for coal beneficiation are due to the following requirements: improving competitiveness of coal products, improvement of quality of marketable products, reduction of coal production cost, environmental requirements: polluting emission abatement, prepared coal saving, improvement of the effectiveness of resource conservation; complex mechanization and beneficiation process automation. In the article the contemporary problems of raw coal benefication under current conditions of the increased dilution of withdrawable coals with rock fractions are considered. Comparative analysis of efficiency of application of modern concentrating equipment under the conditions of the CCPP of OOO «MMK-UGOL» is carried out on the basis of research works. Particular attention is paid to dehydration of produced coal concentrate with content of volatile agents of more than $35.0 \%$ and content of fine-dispersed particles in flotation concentrate of more than $50.0 \%$. Comparative analysis of the coal concentrate dehydration technologies is conducted.
\end{abstract}

\section{Introduction}

Under current mining conditions the coal is re-grinded and the clogging of extracted coal is increased by rock fractions, the thickness of worked layers being reduced. All this determines the need for reequipment and application of progressive processes, effective apparatuses allowing to reduce losses of combustible matter in production wastes, lowering costs of salable production [1-5].

Choice of the optimal technological scheme of beneficiation is the main task of beneficiation specialists. When the raw material base of the coal-preparation plant changes, it becomes necessary to adapt the beneficiation technology. At the same time, under current mining conditions the consumers are placing ever higher demands on the coal concentrate quality and uniformity. When developing new technological schemes, it is always necessary to take into account the environmental requirements for coal-preparation plants.

\footnotetext{
* Corresponding author: office_cof@mmk-coal.ru
} 
Strong volatility in the coal concentrate market dictates the implementation of projects with minimum payback periods.

Thanks to the use of present-day developments and efficient equipment introduction in coal benefication processes the concentrate yield increases and quality of the marketable product improves.

Work objective: Enhancement of operating efficiency of the central coal-preparation plant of OOO «MMK - UGOL».

Work tasks: ash content reduction and increase in concentrate yield, cost reduction, reduction of losses in the raw coal beneficiation, consideration of the efficiency of use of the most advanced technologies in coal beneficiation under the conditions of the central coalpreparation plant of OOO «MMK - UGOL».

\section{Materials and methods}

Situation at present. Existing scheme of the raw coal beneficiation at the central coalpreparation plant of OOO «MMK - UGOL» provides for the operations:

1. 13-150 mm grade beneficiation - using the heavy medium separation method on the wheel separator SKVP-20.

2. 0,5 -13 mm grade beneficiation - using the jigging method on the "Batac" jigs.

3. $0-0,5 \mathrm{~mm}$ grade beneficiation - using the flotation method on the Wemco L144 flotation machines/MFU-12 mechanical flotation machines 2.

Existing problems:

1. Increased clogging of raw coal by rock fractions, reduced concentrate yield and deterioration of the concentrate quality.

2. Imperfection of the water-slurry circuit: presence of circulating loads, content of finedispersed particles in flotation concentrate of more than $50.0 \%$.

Let's consider a solution of the problem of the raw coal clogging by rock fractions, reduction of the concentrate yield and deterioration of the concentrate quality.

For successful achievement of the objective it is necessary to consider the efficiency of the process of the raw coal beneficiation in regards to operations.

For this purpose the research work was carried out by the institute together with the Institute of OOO "Sibniiugleobogashchenie", during which the operation of the technological processes of the coal beneficiation was researched. Data on technological efficiency of the processing equipment during the charge processing with participation of the " $\mathrm{Zh}$ " brand are given in the table 1.

Table 1. Operating efficiency of the processing equipment at the central coal-preparation plant of OOO "MMK - UGOL".

\begin{tabular}{|c|c|c|c|}
\hline $\begin{array}{l}\text { Item } \\
\text { No }\end{array}$ & $\begin{array}{l}\text { Size grade, } \\
\mathbf{m m}\end{array}$ & Beneficiation process name & Process efficiency,$\%$ \\
\hline 1 & $13-150$ & Heavy medium separation & $99.2 \%$ \\
\hline \multirow{2}{*}{2} & \multirow{2}{*}{$0.5-13$} & Jigging: & \\
\cline { 3 - 4 } & & Rock compartment & $89.7 \%$ \\
\cline { 3 - 4 } & $0-0.5$ & Mid-coal compartment & $66.2 \%$ \\
\hline 3 & & Floatation & \\
\hline
\end{tabular}

According to the research data, the least efficient work on the processing equipment in is in the jigging process. The reason for the inefficient operation of the jigging process is a change of the charge washability category from medium to heavy. However, it is common- 
ly known that the jigging process is best suited for easy and average raw coal washability categories, the washability category rise to the heavy one leading to excessive losses of the coal concentrate.

To assess the increase in the raw coal beneficiation, it is necessary to carry out a comparative analysis of the $0.5-13 \mathrm{~mm}$ grade beneficiation by the jigging and heavy medium separation method.

Table 2. Calculation of the practical balance of the $0.5-13 \mathrm{~mm}$ grade coal beneficiation products in heavy medium cyclones.

\begin{tabular}{|c|c|c|c|c|}
\hline \multirow{2}{*}{ Denomination } & \multicolumn{2}{|c|}{ Before implementation } & \multicolumn{2}{c|}{ After implementation } \\
\cline { 2 - 5 } & Yield, \% & Ash content, \% & Yield, \% & Ash content, \% \\
\hline Concentrate & 65.5 & 9.5 & 67.74 & 9.5 \\
\hline Waste & 34.5 & 77.3 & 32.26 & 82.0 \\
\hline Feedstock & 100 & 32.9 & 100 & 32.9 \\
\hline
\end{tabular}

According to the research data, the existing $0.5-13 \mathrm{~mm}$ grade concentrate yield on the jigs at the $9.5 \%$ concentrate ash content is $65.5 \%$ of the feedstock of the jigs.

Due to the use of a more efficient beneficiation process in heavy medium cyclones, the increase in the $0.5-13 \mathrm{~mm}$ grade concentrate yield will amount to $2.24 \%$ of the initial grade, what will amount to $1.52 \%$ in terms of the initial raw coal $(67.9 \%$ of the yield of the raw coal being supplied to the jig). When the jigs are replaced with heavy medium cyclones, the increase in the concentrate yield will be $1.52 \%$ at the $E_{p m}$ separation error index * decrease from $150 \mathrm{~kg} / \mathrm{m} 3$ to $50 \mathrm{~kg} / \mathrm{m} 3$.

$\mathrm{E}_{\mathrm{pm}}$ index (Separation error index) is recommended by the International Organization for Standardization as an international standard for evaluating the efficiency (accuracy) of the coal separation in a suitable separator.

Improvement of the water-slurry circuit.

The plant was the first in Russia in 1994 to install the closed water-slurry circuit.

To install the heavy medium cyclones in replacement of the jigging process, it is necessary to ensure the solid content in the return water and exclude the circulating loads.

To achieve the solid content up to 1 (3) g/l in the return water, it is necessary to obtain a clean filtrate from the flotation concentrate filtration process, the equipment also having to meet the solid high output requirements. At the present moment, the filtrate content less than $3 \mathrm{~g} / \mathrm{l}$ can be obtained by using the modern equipment of the chamber filter presses and hyperbaric disc filters. Chamber filter presses and hyperbaric disc filters are the fully automated equipment that facilitates operation and reduces the human factor.

As a result of the studies in respect of the conditions of the central coal-preparation plant of OOO «MMK - UGOL» despite the pressure difference of 10 bar between two filters (pressure of the chamber filter presses 16 bars and pressure of the hyperbaric disc filters 6 bars), the lowest residual moisture content is $15-18 \%$. A significant difference between the kinds of equipment is the continuous operation of the hyperbaric filters compared to the cyclic operation of the chamber filter presses. Continuous flotation concentrate filtration operation with due regard to the residual moisture content reduction from $27.0 \%$ to $18.0 \%$ will improve the values of the thermal drying of the concentrate. It is worth noting the improvement of the technological parameters of the thermal drying, what is especially important because the release of volatile substances as for the " $\mathrm{Zh}$ " brand is higher than $35.0 \%$, also allowing to reduce the thermal drying costs.

It is also very important that the filtration will be carried out with the flotation concentrate having the content of fine-dispersed particles of more than $50.0 \%$.

Table 3. Granulometric composition of the flotation concentrate. 


\begin{tabular}{|c|c|c|}
\hline Size grade, $\mathbf{m m}$ & Content,\% & Ash content,\% \\
\hline+1.0 & - & - \\
\hline $0.5-1.0$ & 1.3 & 3.9 \\
\hline $0.3-0.5$ & 5.5 & 3.9 \\
\hline $0.2-0.3$ & 11.2 & 4.1 \\
\hline $0.1-0.2$ & 20.8 & 5.2 \\
\hline $0.05-0.1$ & 19.5 & 7.0 \\
\hline $0-0.05$ & 41.7 & 19.6 \\
\hline Total & 100.0 & 11.3 \\
\hline
\end{tabular}

To ensure the operation of the water-slurry circuit in a closed loop in addition to the equipment already installed, it is required to install a radial thickener with two belt filter presses for the flotation tailings, using the anionic and cationic flocculate in the thickening and filtration processes to intensify the process.

By reducing the circulating loads, concentrate clogging with slurry, the increase in the concentrate yield will be $1.48 \%$ (due to the increase in the specific gravities of the separation in the gravitational processes of the beneficiation).

Impact of the project on the environment. Due to the flotation concentrate moisture content reduction from $27.0 \%$ to $18.0 \%$ during the filtration process, it will allow to reduce the environmental emission by 95 th $\mathrm{m} 3$ year during the thermal drying of the concentrate. Increase in the concentrate yield will allow to reduce the amount of beneficiation waste coal stored on the rock dump by 118,437 th $\mathrm{t} / \mathrm{y}$.

Cost-benefit analysis of re-equipment of the central coal-preparation plant of OOO «MMK - UGOL».

Table 4. Operating highlights of the re-equipment implementation.

\begin{tabular}{|l|c|c|c|}
\hline \multicolumn{1}{|c|}{ Denomination } & $\begin{array}{c}\text { Before } \\
\text { implementation }\end{array}$ & $\begin{array}{c}\text { After } \\
\text { implementation }\end{array}$ & $\begin{array}{c}\text { Deviation } \\
+/-\end{array}$ \\
\hline Concentrate yield.\% & 50.3 & 53.3 & 3.0 \\
\hline Concentrate ash content.\% & 10.8 & 9.5 & -1.3 \\
\hline $\begin{array}{l}\text { Environmental emission abatement. t } \\
\mathrm{m}^{3}\end{array}$ & 285 & 190 & 95 \\
\hline $\begin{array}{l}\text { Reduction of the amount of beneficia- } \\
\text { tion waste coal stored on the rock } \\
\text { dump. th } \mathrm{t}\end{array}$ & 1922.6 & 1804.2 & 118.4 \\
\hline
\end{tabular}

Table 5 List of costs of the re-equipment implementation

\begin{tabular}{|c|c|c|c|}
\hline $\begin{array}{l}\text { Item } \\
\text { No }\end{array}$ & Denomination & Quantity, units & $\begin{array}{l}\text { Costs of the } \\
\text { reequipment, } \\
\text { thousand USD }\end{array}$ \\
\hline 1 & Throw screens & 10 & \multirow{10}{*}{9456} \\
\hline 2 & Heavy medium cyclone & 2 & \\
\hline 3 & Outlet sieve bends & 10 & \\
\hline 4 & $\begin{array}{l}\text { Magnetic separators with permanent mag- } \\
\text { nets }\end{array}$ & 4 & \\
\hline 5 & Radial thickener & 1 & \\
\hline 6 & Hyperbaric filter & 2 & \\
\hline 7 & Project design work & & \\
\hline 8 & Construction and installation operations & & \\
\hline 9 & Costs of technological materials & & \\
\hline 10 & TOTAL & & \\
\hline
\end{tabular}


Table 6 Calculation of net annual income from project implementation

\begin{tabular}{|l|l|c|}
\hline $\begin{array}{l}\text { Item } \\
\text { No }\end{array}$ & \multicolumn{1}{|c|}{ Denomination } & Quantity \\
\hline 1 & Annual volume of raw coal processing. th t & 3947.884 \\
\hline 2 & Expected minimum increase in concentrate yield. \% & 3.0 \\
\hline 3 & Cost of concentrate in market (min). USD/t & 120 \\
\hline 4 & Increase in concentrate output will be. th t & 118.4 \\
\hline 5 & Increase in income from output. th USD & 14212 \\
\hline 6 & $\begin{array}{l}\text { Reduced equipment repair costs (reduction in quantity of units } \\
\text { of equipment). th USD }\end{array}$ & 240 \\
\hline 7 & $\begin{array}{l}\text { Energy usage reduction (reduction in quantity of units of } \\
\text { equipment). th USD }\end{array}$ & 134.9 \\
\hline 8 & \begin{tabular}{l} 
Income from improving the concentrate quality. th USD \\
\hline 9
\end{tabular} & Reduction in expenses for removal of waste. th USD \\
\hline 10 & Reduction of waste storage costs. th USD & 6275.6 \\
\hline 11 & Property tax. th USD & 85.5 \\
\hline 12 & Profit tax. th USD & -190.6 \\
\hline 13 & TOTAL net annual income from the project & -4134.4 \\
\hline
\end{tabular}

Total payback period of the project is 7 months.

\section{Conclusion}

On the basis of the article it is possible to draw a conclusion on the possibility of increasing the efficiency of coal-preparation plants under current conditions by reequipment: replacement of equipment - jigs with heavy medium cyclones, modernization of the water-slurry circuit (elimination of circulating loads, reduction of the concentrate clogging by slimes), what will allow to increase the concentrate yield, improve the concentrate quality in terms of the ash content value, reduce the equipment operating costs, abate the environmental emissions (by reducing the floatation concentrate moisture content).

\section{References}

1. L.A. Antipenko, Ugol', 2, 87 (2017)

2. A.V. Bauman, XVIII International Coal Preparation Congress, 345-351 (2016)

3. A. Sherritt, G. Jones, A. O'Keeffe, Int. J. Coal Prep. Util. 5, 67-74 (2014)

4. A.D. Meyers, G. Sherritt, International Coal Preparation Congress, 334-340 (2010)

5. E. Bekker, XVIII International Coal Preparation Congress, 233-240 (2016) 
